\title{
The pain of existing and religion from the perspective of Catholics ${ }^{1}$
}

\author{
Simone Saltareli \\ Talita de Cássia Raminelli-da-Silva ${ }^{3}$ \\ Ana Carolina Ferreira Castanho ${ }^{4}$ \\ Rodrigo Ramon Falconi-Gomez ${ }^{5}$ \\ Orlando Carlos Gomes Colhado ${ }^{6}$ \\ Fátima Aparecida Emm Faleiros-Sousa ${ }^{7}$
}

\begin{abstract}
Objective: to characterize the understanding of leaders and members of the Catholic religion on pain of existing. Method: 80 Catholics participated in the study. Data collection was carried out using the Religious Content Assessment Tool. The content analysis was carried out and arithmetic mean and standard deviation were calculated. Results: the following categories emerged: length of affiliation, beginning of the religious practice and affiliation changes, responsibility for the actions and relationship with death, description of God, awareness of the existence of profound experiences, possibility of reward, increased faith in proximity to death, religion as an attempt to explain human limitations, relationship between religion and science and religion of the past and present in relation to science. On the instrument, the highest assigning items were: I believe that nature should be respected ( $9.96 \pm 0.19)$; I believe that all living beings deserve respect (9.70 \pm 0.67$)$; make life worth living (9.70 \pm 0.78$)$; my life is a transformation process $(9.63 \pm 1.04)$ and I respect the diversity of people (9.56 \pm 0.91$)$. Conclusion: it was observed associations between the participants' perceptions and religious constructs, highlighting the need to approach the religious phenomenon as part of the human being and potential resource for management and modulation of the pain of existing.
\end{abstract}

Descriptors: Pain; Religion; Evaluation; Death.

1 Paper extracted from doctoral dissertation "Management of pain of existence through religion: one possibility of meeting with yourself", presented to Escola de Enfermagem de Ribeirão Preto, Universidade de São Paulo, PAHO/WHO Collaborating Centre for Nursing Research Development, Ribeirão Preto, SP, Brazil.

2 Doctoral student, Escola de Enfermagem de Ribeirão Preto, Universidade de São Paulo, PAHO/WHO Collaborating Centre for Nursing Research Development, Ribeirão Preto, SP, Brazil.

${ }^{3}$ Doctoral student, Escola de Enfermagem de Ribeirão Preto, Universidade de São Paulo, PAHO/WHO Collaborating Centre for Nursing Research Development, Ribeirão Preto, SP, Brazil. Scholarship holder from Conselho Nacional de Desenvolvimento Científico e Tecnológico (CNPq), Brazil.

${ }^{4}$ Master's student, Escola de Enfermagem de Ribeirão Preto, Universidade de São Paulo, PAHO/WHO Collaborating Centre for Nursing Research Development, Ribeirão Preto, SP, Brazil. Professor, Universidade Paulista, Ribeirão Preto, SP, Brazil.

${ }^{5}$ Undergraduate student in Psychology, Universidade Paulista, Ribeirão Preto, SP, Brazil. Scholarship holder from Fundação de Amparo à Pesquisa do Estado de São Paulo (FAPESP), Brazil.

${ }^{6} \mathrm{PhD}$, Associate Professor, Departamento de Medicina, Universidade Estadual de Maringá, Maringá, MG, Brazil.

7 PhD, Full Professor, Escola de Enfermagem de Ribeirão Preto, Universidade de São Paulo, PAHO/WHO Collaborating Centre for Nursing Research Development, Ribeirão Preto, SP, Brazil.

Corresponding Author:

Simone Saltareli

Rua Quirino Roquetti, 263

Bairro: City Ribeirão

CEP: 14021-070, Ribeirão Preto, SP, Brasil

E-mail: ssaltareli@yahoo.com.br
Copyright $\odot 2015$ Revista Latino-Americana de Enfermagem This is an Open Access article distributed under the terms of the Creative Commons Attribution Non-Commercial License (CC BY-NC).

This license lets others distribute, remix, tweak, and build upon your work non-commercially, and although their new works must also acknowledge you and be non-commercial, they don't have to license their derivative works on the same terms. 


\section{Introduction}

The concept of total pain ${ }^{(1)}$ is defined as the suffering that can be physical, mental, social, spiritual, family, among others. This concept shows clearly the need to extend the view of the human being as a biopsychosocial and spiritual being, enabling the understanding of the complexity of the phenomenon of pain.

In consonance with the concept of total pain, the pain of existing is the pain of the human being facing death and presenting itself as a challenge in this sense, since it is necessary that the source of knowledge develop resources, so that pain can be communicated, and therefore, properly managed. Religion is one of the resources for the management of the pain of existing, which is becoming more popular in the scientific community ${ }^{(2-3)}$.

Several authors discuss the interest that has been perceived on the relationship between pain and religiosity, which is consistent with the concept of total pain ${ }^{(4-6)}$. Authors report that the search for biopsychosocial and spiritual balance has never been so perceived, with studies inclusive indicating secondary physiological changes to spirituality and religiosity, regardless of religious denomination ${ }^{(7)}$.

Religion is a way of trying to cope with the distress caused by the proximity and visualization of finitude, representing a belief system, with traditions that involve rituals, symbols and a construction of meanings towards death $^{(8)}$.

Data from the Brazilian Institute of Geography and Statistics (IBGE) pointed, in the census carried out in 2010, a distribution of beliefs or religions of around 50 denominations across the country, totaling 190,755,799 people who report having some belief or religion. Due to the large number of religious denominations, it was opted in this study by addressing only the Catholic religion, because of its greater representation, consisting of $64.6 \%$ of the religious in the Brazilian population ${ }^{(9)}$.

In Catholicism, as well as in other Christian religions, death is seen according to the concept of Easter, this being the model for understanding of both the death itself as the rites of passage instituted and practiced. In this view, human death does not mean the end of life, but rather, a passage to an infinitely wider existence, representing a direct contact with $\operatorname{God}^{(10)}$.

To evaluate the perception of pain and its multidimensionality is a huge challenge, since it is not enough to know only the etiology of the pain. It is also necessary to be alert to the human suffering, from the perception and expression of those who experience the feeling of pain, regardless of how this pain presents itself for the human being ${ }^{(11)}$.

It has not been found in the available databases, scales for assessment or evaluation of the pain of existing associated with religion, or even a tool that could capture specificities of each religious segment and their relationship to pain.

It is highlighted, therefore, the importance of the pain of existing as theme, associated with religiosity, in consonance with the concept of total pain, so that the human being can be understood in all its complexity and biopsychosocial and spiritual magnitude and even designed as a man being entirely man, inserted in an infinitely complex context.

\section{Objective}

To characterize the understanding of leaders and members of the Catholic religion on the pain of existing.

\section{Method}

\section{Type of study}

It is a qualitative and descriptive study. It included 40 leaders and 40 affiliates of the Catholic religion who lived in a city in the state of São Paulo. It was used paper, pen, pencil and rubber, for printing and completing the instrument.

In accordance with Resolution Number 196/96, for research on Humans, the Ethics Committee of the Nursing School of Ribeirão Preto - University of São Paulo, approved this study, under Opinion Number 236.138. It was used the Informed Consent Form (IC) for carrying out the study.

For data collection, it was used an interview and a scale developed by the own authors of the Religious Content Assessment Tool (IACOR). The interview consisted of sociodemographic questions, such as age, length of religious affiliation, among others, as well as ten questions about the general perceptions of leaders and members of the Catholic religion, based on the themes addressed in the literature, in order to expand the understanding of this phenomenon. The scale was developed based on previously validated scales, identified in the international literature and on the authorship's experience. Following a survey of the items to compose the scale, these items have been validated, regarding their apparent form and content, by five judges (three 
theologians, a physician and a psychologist). Following this procedure, there was a reduction from 781 to 74 items. Other four items were added, resulting from the suggestions of the judges, totaling 78 items in its final form.

Contacts with Catholic churches were previous made by telephone and in person, for scheduling. All participants were naive about the instruments, i.e. they did not previously know any of the items proposed in the instruments. Such ingenuity is verified since this is a new instrument, developed by the authors.

Prior to the application of the instrument, the Informed Consent Form (IC) was presented to participants, which was read and signed by them. Subsequently, there was a semi-structured interview and then, the scale containing the attributes related to the pain of existing was applied. The task to be performed by the participant is described at the beginning of the instrument, which should be to read before its performance.

The authors conducted a semi-structured interview, and the participants' task was to report their opinion about the topics addressed.

During the application of the scale, the participants' task was to demonstrate, by means of an 11 points rating scale (0-10), how the participant agreed with each statement. Participants were instructed to assign any of the scores that better represented their judgment. In this fashion, the less they agreed, the closer to 0 (zero) the score should be, and the more they agreed, the closer to 10 (ten) the score should be.

\section{Data analysis}

Interviews were drafted for carrying out the qualitative analysis, using the thematic content analysis technique, in order to organize the material, so that this could be systematized into categories of analysis, facilitating the understanding of the phenomenon.

The categories of analysis were developed according to the questions proposed in the interview and the structured subcategories respected the individuality of the groups. It was calculated the arithmetic averages and standard deviations of the data of the scale.

\section{Results}

The participantes were 80 individuals belonging to the Catholic religion, of which 40 were affiliates (CAT$A F)$ and 40 were leaders (CAT-LD). The data show that average age of the CAT-LD group was 50.30 years, which was higher than the CAT-AF group with an average of 37.64 years. The number of male participants in the CAT-LD group was also higher, with $57.50 \%$ of the sample, and the number of female participants was higher in the CAT-AF group, with $80 \%$ of the sample. Most participants of the CAT-AF group, $87.50 \%$, is included in the group of economically active persons. In the CAT-LD group, $100 \%$ of the participants are active, with the largest groups of priests, representing $52.50 \%$ of the sample and $42.50 \%$ were consecrated or nuns. Most members of the CAT-AF group reported no other religion prior to the Catholic, totaling 95\% of the group and a leader of this religion reported experiences in other religions, representing $2.5 \%$ of the sample.

Regarding the categories of analysis, these were developed based on the content analysis and according to the questions proposed in the interview. The subcategories structured in each question respected the individuality of the groups, due to the different views and understandings on each way of living religiosity and the relationship of these with the pain of existing when confronting the situation of death. There were 10 listed categories, which are described below.

\section{Interviews of Catholic groups (CAT-AF $n=40$ and CAT- LD $n=40$ )}

\section{1) Lenght of affiliation}

Regarding the lenght of religious affiliation, the CATAF group showed variation from 3 to 65 years, average of 32.17 years of participation in activities related to the Catholic Church. As for the CAT-LD group, this period ranged from 20 to 92 years, with average of 47.33 years of participation in the Catholic religion. The way the participants defined their participation was respected, regardless of if the decision was conscious or not.

Well ... if I am 92 years old and I am Catholic since I was born, because I come from a Catholic family, so I can say I have been Catholic for 92 years!! (CAT-LD 29).

2) Beginning of the religious practice and affiliation changes

Regarding the spontaneous religious practice in the CAT-AF group, 30\% reported having begun in childhood, $22.5 \%$ during adolescence, $10 \%$ in adulthood and $37.5 \%$ reported a natural process, in which there was no determination for the beginning of the spontaneous 
search. There was $5 \%$ of change of religious affiliation in this group.

I started since I was a child to go willingly, and participate in the altar boys group, I was around 8 years old (CAT-AF20).

In the CAT-LD group, $42.5 \%$ reported spontaneous search in childhood; $37.5 \%$ during adolescence, $2.5 \%$ in adulthood and $17.5 \%$ did not specifically identify a period.

It is difficult to know how it started spontaneously, because it was so natural that flowed, it came along with consciousness, with the will (CAT-LD35).

3) Responsibility for the actions and relationship with death

In the CAT-AF group, $67.5 \%$ believed that the individual is fully responsible for his/her actions and life situations, $30 \%$ believed that this responsibility is partial and $2.5 \%$ believed that this responsibility does not dependent of any issue related to death or religiosity.

According to opinion of the CAT-LD group on the theme, $80 \%$ believed that it is a full responsibility of the human being in relation to the actions and life situation and $20 \%$ believed that it is a partial responsibility.

Thus, it is clear that for most participants from both groups, the human beings have full responsibility for their actions, as well as the resulting consequences of these in their lives, and are therefore, also responsible for their death.

You are the responsible, so you cannot blame anyone. It is an arrival, and when you get older, you realize more clearly that you pass by little deaths over the years. Moreover, we are going to realize that we are getting older and it's painful because we need to accept it (...) (CAT-LD35).

\section{4) Description of God}

In this category, it was possible to observe how the participants characterize God and how they define Him. In the description of the participants of both groups, it was evident some differences in the quality of attributes related to the description of God. The descriptor most assigned, for example, refers to the personified form of picturing or describing God, as shown below.

The image is that most represented by the European culture: someone older, wiser, a wiser man, source of wisdom. A man whom Christ himself has taught us to call Father (CAT-LD9).

There are also comprehensive descriptions with characteristics involving both physical and abstract aspects such as, for example, the descriptors "everything" and "inexplicable".

\section{5) Awareness of the existence of profound experiences}

On the questioning about the theme, participants of the CAT-AF group expressed themselves in three different ways: $75 \%$ believed that most people are aware that there are deep experiences, which can not be explained or verbalized, referring to supernatural experiences or experiences with God, 7.5\% believed that people in general do not have this awareness and finally, $17.5 \%$ believed that this awareness, or lack of it, is distributed in a heterogeneous fashion in the general population.

In the CAT-LD group, participants' responses show that $70 \%$ believed so, $5 \%$ believed that people do not have this awareness and $25 \%$ believed that only part of the population have this awareness.

Thus, most participants from both groups believed in the expression of something supernatural linked to religion in their lives.

Yes, I think people have this awareness. Just as there are things that are just ours. There is always in the human beings, things that are their own, and one of those things is the experience of God, which should not be invaded (CAT-LD6).

\section{6) Possibility of reward}

With regard to the possibility of reward after death, $27.5 \%$ of participants of the CAT-AF group reported to believe tha there is, $22 \%$ of them do not believe and $17.5 \%$ believed that it depends on the understanding of the use of the word "reward".

In the CAT-LD group, $52.5 \%$ said they believed that there is reward after death, and $40 \%$ believed that this reward is to be in God's presence and $12.5 \%$ believed that it would be the love of God. The leaders who reported they did not believe totalled $32.5 \%$.

In the group of leaders, most of them believed that there is reward after death, so it is observed association between the lives of individuals and life after death. Although not majority, many participants expressed this point of view in the group of affiliates.

I believe so. Not only by faith, but also by death itself, I think there are good things after death. I think in our case, we expect the resurrection, giving up of suffering and having love as reward after death (CAT-LD3).

7) Increased faith with proximity to death

Of the participants of the CAT-AF group, $65 \%$ believed that faith increases and $25 \%$ of participants believed that faith does not increase with the proximity of death.

In the CAT-LD group, 55\% believed that faith increases, $17.5 \%$ believed that death is not associated with the increase of faith and $27.5 \%$ believed that there are few situations in which faith may increase, but not in all of them. 
Again, for both groups, most believed in the increase of faith, as death approaches, as evidenced by the report below.

I believe that, when someone is close to death, his/her faith increases and increasing faith, he/she is even closer to God. The person can regret of his/her errors; he/she reflects more on life and seeks God more fervently to get closer and be forgiven by Him (CAT-AF26).

8) Religion as an attempt to explain human limitations

Of the participants of the CAT-AF group, $50 \%$ believed that religion has the role of trying to explain the limitations of human beings, perceived by them and $35 \%$ believed that religion has other roles than to explain human limitations.

Human beings are limited. Religion tries to explain, but it is necessary to evaluate if we can put it into practice, rationalize it (...) (CAT-AF6).

In the CAT-LD group, $57.5 \%$ of participants believed so, $32.5 \%$ do not believe and $10 \%$ of the group reported to believe in the association between both to explain human limitations.

(...) Nowadays, people have education and religion helps in their thoughts and proposes a Christian way of living (CATLD14).

(...) The mission of the religion is to make people to grow in their faith, keep their faith, and this is a gift, a grace from God (...) (CAT-LD37).

Yes, I do believe, due to the relationship between faith and reason. Neither side has full explanations. Both have limitations. One completes the other (...) (CAT-LD13).

\section{9) Relationship between religion and science}

In the CAT-AF group, $85 \%$ reported that there are divergences, and the most frequently observed divergence is the contradiction betwen reason and faith or belief and $7.5 \%$ of the group believed that there are no divergences between them and $7.5 \%$ believed that there is an increasing convergence between the positions of science and religion.

(...) However, religion exceeds science. Due to the ancestral tradition that it carries, religion is more consolidated than science ... But one does not progress without the other. Moreover, people go to the same place after death, both the religious and the scientist (CAT-AF16).

In the CAT-LD group, $67.5 \%$ identified that there are divergences, with the main one being about the opposition between reason and belief, $7.5 \%$ believed that there are no divergences, $25 \%$ reported increased approach between religion and science, in some cases, depending on the use made by the actors in this context.

10) Religion of the past and present in relation to science In the CAT-AF group, $92.5 \%$ answered that there is difference between the religion of the past and the present.

I think there is difference, because people and things change over time, but I do not believe that theology is based on something scientific, because religion does not try to prove anything or experience things. People who follow the religion, do it without the need to prove something, but because they believe that (CAT-AF4).

In the CAT-LD group, $72.5 \%$ believed that there are differences and $27.5 \%$ believed that there are no differences between the religion of the past and today.

Regarding the items (78) of the IACOR instrument, it follows below the description of the 5 attributes with the highest and lowest assigning.

The attributes with the highest assigning were: I believe that nature should be respected, AM: 9.96, standard deviation (SD): 0.19; I believe that all living beings deserve respect, $A M$ : 9.70, SD: 0.67; to make life worth living, AM: 9.70, SD: 0.78; my life is a transformation process, AM: 9.63, SD: 1.04; I respect the diversity of people, AM: 9.56, SD: 0.91.

The attributes with the lowest assigning were: there is no life after death, AM: 1.21, SD: 2.72; I tried to handle the situation on my own, without the help of God, AM: 1.59, SD: 2.57; a person can be complete without seeking an active spiritual life, AM: 1.85, SD: 3.12; I imagined what it would have done for God to punish me, AM: 1.90, SD: 2.80; I do not accept changes brought about in my life as a result of losses, AM: 2.08, SD: 2.88 .

\section{Discussion}

In this study, it was found a high rate of participants with complete higher education, especially in the CAT-LD group. This may be related to the requirement of higher education, linked to the figure of the leader, which must be of the male gender, in the Catholic religion. The census of the IBGE characterized the sample of Catholics in Brazil, indicating prevalence of incomplete elementary education, totaling $39.8 \%{ }^{(9)}$.

The beginning of the religious practice in the study group is linked to participation in groups associated to the Catholic rites, such as the altar boys, the catechists etc. It is important to understand the meaning of the practice 
of the devotional rites, since they express the possibility, for the faithful member, to revive the original time of the events that characterize their religious denomination. Accordingly, it is essential to recognize the importance of the development of these rites to better understand the meaning of the religious universe ${ }^{(12)}$.

To explain the sense of responsibility reported by most participants, it is discussed that Christianity maintains the idea of legacy of Adam and Eve and their disobedience to God. This matter refers to the process known as fall of man, in which the human beings assume the condition of not being more under divine responsibility, with their actions under their full responsibility ${ }^{(13)}$

With regard to the descriptions of God, these are closely linked to the question of the personification, i.e., attributing human physical characteristics to God. Think of the figure of Jesus Christ is to consider the backbone of Christian eschatology, therefore, based on this conception, salvation is attained through Christ ${ }^{(14)}$.

It is also observed that most participants reported believing in the consciousness of the existence of profound experiences. The transcendent is the prospect of going beyond itself and, in this view, human beings always search for that when they feel the need for something beyond themselves. It can be observed from the reports that, in certain situations, the search for that something beyond itself may find its expression in the religion, which the author states to be the path to the answers of the human beings ${ }^{(15)}$.

In the reports of participants, it is observed that the idea of reward is linked to the idea of reaching paradise and to be closer to God, both in the CAT-AF group as in the CAT-LD group, which presented an even greater number of participants who believed in the possibility of reward. Religiosity helps in the way of acting of human beings, so that these can be prepared for death and, in Christianity there is a relationship between the repentance of sins and the reward to be in the presence of God after death, reserved for those who love and obey $\mathrm{Him}^{(16)}$.

To discuss the issue of increasing faith with proximity to death, it is emphasized that the Christian faith brings the hope of salvation because it is directly associated with the resurrection and eternal life, and this idea gives meaning to death. If had not been for the view of continuity, death would have no meaning within the belief, which emphasizes that, by living in accordance with the purposes of God, there will be life with Him after death(14).
Most participants understand that religion tries to explain human limitations. A review discusses the association of religion as something positive, on issues such as stress, substance abuse, psychosis, depression, anxiety, suicide, among others. Religion offers comfort, meanings and hope for individuals in these situations ${ }^{(17)}$. The findings of the study corroborate the observations pointed by participants who believed that religion has the role to offer explanations to humans about their limitations. It is observed that not everyone agreed with this role of religion or believed that religion is completely responsible for this function. There are participants who believed that religion helps, but it should not provide all necessary explanations for the human limitations.

Regarding the relationship between religion and science, it is observed that in both groups, the main divergence concerns the opposition between reason and belief, or faith and reason. Officially, the position of the Catholic Church regarding the association between science and faith, is a position of complementarity and support in the development of the human beings ${ }^{(18)}$.

The position indicated by the majority of the group is a position of conflict, when it comes to people with extreme views such as, for example, biblical literalists who believe that evolutionary theory conflicts with faith ${ }^{(19)}$.

By comparing the religion of the present and the past, survey data show that most participants believed in the difference between religion of past and present. It can be explained by the discussion, which says that, since the beginning of the Christian religion to the present, changes and adaptations have been proposed, and several councils occurred in the Catholic Church throughout history, which are meetings of church leaders to discuss both doctrinal and disciplinary issues. In the Catholic Church, 21 councils were carried out, in all, and the last one was held between 1962 and 1965. In these events, theological aspects of the new proposals are also discussed ${ }^{(20)}$. In the reports of the participants, there is a prevailing perception about the changes proposed, but these changes not necessarily occurred due to science.

With respect to the items of the scale with the highest assigning, the first two items are related to the respect assigned to the relationship with the environment, as part of creation. The next three are related to general ideas about life, considering its importance, dynamism and meaning.

With regard to the items with the lowest assigning, the first refers to the idea of life after death without continuity, which can be understood according to the 
notion of death used by participants to assign scores to the sentences. The second item relates to the negative relationship with God that, due to the fact of being among the less assigned, is understood as the rejection of this idea by Catholic groups. The third refers to the possibility to feel full without spiritual practice. The fourth is about the notion of a punitive God, which is consistent with the understanding of the Christian religions about creation, fall of man and human redemption. The fifth reveals the difficulty of dealing with losses, i.e., elaboration of the grieving process, which means that for the Catholic groups, this difficulty can be overcome, with acceptance of the changes resulting from losses.

In the official Vatican website, the central objectives postulated are presented: the Church's mission is to bring the Gospel to all, as an instrument of intimate union with God and with every human being. God's design is developed based on the fact that God must be considered as absolute, so that the relationship among people can be fraternal, with Jesus Christ coming to the world to realize the plan of God, his Father(21).

It is also observed that there was progress in the Catholicism's notion about death, ideas of condemnation to hell and death serving this purpose, as the punishment of sin, becoming to be understood without the elements of threat. These give rise to the notion that after death, God proposes the resurrection, since the human beings agree to evolute, according to the criteria proposed by God Himself. ${ }^{(10)}$

It is observed that, for both groups of this study, there is the recognition of the condition known as the fall of man, with the recognition that men are responsible for their actions and life situations. The description of God reflects aspects of both creation and redemption, with the statement that there is the saving will of the Father. In the same context, there is the expression of respect for God's creation, according to the items of the scale with the highest assigning. This demonstrates the perception of intimate union with God, as well as items that relate to the positive relationship with God.

Thereby, it is observed that there are several aspects expressed by participants of Catholic groups that directly relate to those proposed by the official representative body of the Catholic Church.

\section{Conclusion}

The study highlights the need to understand and address the religious phenomenon as an integral part of human beings, as well as a potential management resource of the pain of existing, expressed by pain on issues related to death, finitude and hopelessness.

In the comparative analysis between the interviews and the scale of the IACOR, it was observed associations between participants' perceptions and religious constructs of the group to which they belong. It shows that they were able to clearly express the relationship established between the pain of existing and the religion to which they belong, regardless of participating as leaders or as affiliates in these religions.

Given the complexity of the phenomenon, regarding the pain of existing and religion, future studies are needed to gradually increase the dialogue between religion and science. Consequently, this could enable the expanding the possibilities of resources and approaches, which aimed at prompting the professionals responsible for pain management, for the recognition and the respect needed for the clinical practice and research development.

\section{References}

1. Saunders C. Hospice and palliative care. An interdisciplinary approach. London: Edward Arnold; 1991.

2. Lucchetti G, Granero AL, Bassi RM, Latorraca R, Nacif SAP. Espiritualidade na prática clínica: o que o clínico deve saber? Rev Bras Clin Med. 2010;8(2):154-8.

3. Nogueira M, Teixeira MJ. Central pain due to stroke: cognitive representation and coping according to gender. Arq Neuropsiquiatr. 2012;70(2):125-8.

4. Corrêa DAM. Religião e saúde: Um estudo sobre as representações do fiel carismático sobre os processos de recuperação de enfermidades nos grupos de oração da RCC em Maringá, PR. Ciênc Cuidado Saúde. 2006;5:134-41.

5. Jonhstone B, Franklin KL, Yoon DP, Burris J, Shigaki

C. Relationships Among Religiousness, Spirituality, and Health for Individuals with Stroke. J Clin Psychol Med Settings. 2008;15:308-13.

6. Carqueja E. A prática religiosa e a percepção do sofrimento: um estudo em doentes com cancro e em doentes com dor crônica. Cad Saúde. 2009;2(1):7-40.

7. Lago-Rizzardi CD, Teixeira MJ, Siqueira SRDT. Espiritualidade e religiosidade no enfrentamento da dor. O Mundo da Saúde. 2010;34(4):483-7.

8. Kovács MJ. Espiritualidade e psicologia - cuidados compartilhados. O Mundo da Saúde. 2007;31(2):246-55. 9. Instituto Brasileiro de Geografia e estatística (IBGE). [Internet]. [acesso 12 jan 2012]; Disponível em: 
http://www.ibge.gov.br/home/estatistica/populacao/ censo2010/populacao/religiao_Censo2010.pdf

10. Blank R. Catolicismo: Ritos de Passagem e Visão de Pós-Morte. In: Incontri D, Santana F, organizadores. A Arte de Morrer - Visões Plurais. Bragança Paulista: Editora Comenius; 2007.

11. Faleiros Sousa FAE, Pereira LV, Cardoso R, Hortense P. Multidimensional Pain Avaliation Scale. Rev. LatinoAm. Enfermagem. 2010;18(1):3-10.

12. Couto ES. Devoções, festas e ritos: algumas considerações. Rev Bras História Religiões. 2008;1(1):110.

13. Pinheiro RA. Dor e Religião. Rev Dor. 2007;8(4):1113-5. 14. Belini LA. Temas de Escatologia. Paraná: Humanitas Vivens; 2009. $136 \mathrm{p}$.

15. Boff L. Tempo de transcendência: o ser humano como um projeto infinito. Petrópolis: Vozes; 2009. 85 p. 16. Diniz AC, Aquino TAA. A relação da religiosidade com as visões de morte. Religare. 2009;(6):101-3.

17. Koenig HG. Research on Religion, Spirituality and Mental Health: A Review. Can J Psychiatry. 2009;54(5):283-91.

18. Wojtyla K. Relações entre Fé e Razão. [Internet]. 1998. [acesso 12 jan 2012]; Disponível em: http:// www.vatican.va/holy_father/john_paul_ii/encyclicals/ documents/hf_jp-ii_enc_15101998_fides-et-ratio_ po.html.

19. Sanches MA, Danilas S. Busca de harmonia entre religião e ciência no Brasil: reflexões a partir do ano de Darwin. Teocomunicação. 2012;42(1):98-118.

20. Libanio JB. Concílio Vaticano II- Em busca de um primeira compreensão. São Paulo: Edições Loyola; 2005. 223 p.

21. Vaticano. Constituição Dogmática Lumen Gentium. [Internet]. Itália; 1964. [acesso 24 abr 2014]. Disponível em: http://www.vatican.va/archive/hist_councils/ ii_vatican_council/documents/vat-ii_const_19641121_ lumen-gentium_po.html. 